data giving the results of treatment, ranging in some cases over so much as fifteen years, and rarely so little as five. The data, taken in conjunction with those issued by the National Radium Commission, are in effect the answer to the question: What is the value of radium in the treatment of cancer? There are sites, such as the csophagus and rectum, where the data show that a permanent improvement in the condition is not as a rule to be expected. On the other hand, a patient exhibiting an early stage of the disease in cancer of the cervix uteri is after suitable radium treatment more likely than not to be free of the disease five to six years later.

Methods change, and the tendency for the last few years has been to avoid interstitial methods and replace them by the use of radium outside the body. Teleradium has been practised by several centres in Great Britain over a period of years, and an interesting account is given of the clinical uses of a one gram unit at the Middlesex Hospital.
Reference to the experimental section shows that researches essential to our understanding of the biological actions are being undertaken by several groups, notably at the Strangeways Laboratory at Cambridge, the Imperial College of Science and Technology, the Royal Cancer Hospital, the Mount Vernon Research Centre and at the Middlesex Hospital. As stated in the introduction, with leading principles being established, the make-shift ground of empiricism gives way to a surer basis of therapy. That basis is quickly becoming a scientific one, in the sense that doses of radiation are now prescribed and dispensed in a quantitative manner; this has been brought about only by long effort, an important step being the establishment of the rontgen as an X-ray unit. The Medical Research Council, systematically and over a course of years, has aided the work of the British $\mathrm{X}$-ray Unit Committee, which had much to do with fixing the value of the unit now in general use.

\title{
Cultural Successions in British Archæology
}

$\mathrm{B}$ RITISH archæology, perhaps, has profited more than any other field of archæological investigation by the recent diversion of interest from the more striking products of a culture to the building up of a culture complex as a whole. By this means it is now becoming possible to trace in greater detail and with more certainty the racial and cultural successions in Britain, and their interrelations, which went to make up the composite product appearing in these islands on the threshold of historic times. Hence the importance of such sites as Maiden Castle, St. Albans and Wheathampstead, on which more or less continuous or contiguous occupation over a comparatively long period affords an opportunity to follow the changes and modifications brought about by successive cultures.

These great sites, however, are exceptional ; but an analogous opportunity, if on a somewhat lesser scale, is afforded for northern England by Eddisbury Hill, the Cheshire hill-fort, of which the recent excavation was described by Mr. W. J. Varley before the Ancient Monuments Society of Manchester on December 6. Here no less than six distinct cultural periods have been observed in the earthwork defences on the crest of the hill. A period of open occupation at the very close of the Bronze Age is represented by burial urns. This was followed by an immigration from the south, which was responsible for the largest hill-fort known in the north of England. An elaborate system of ramparts, ditches and entrances was built up during the first century B.c. This was still further enlarged under the threat of invasion by the Romans. This defensive system exceeds in complexity that of any other known Iron Age hill-fort in Britain. During the Roman occupation the rampart was dismantled and the ditches filled in. The hill lost its defensive character ; and in late Roman times there is evidence of the floors of an open site occupation. The last cultural phase is early Saxon, of which relics have been discovered in a hut built over a filled-in ditch between two ramparts. Of traces of the Danish invasion none has hitherto been found; but excavation is not yet complete.

Another instance of a succession of occupations comes from Welwyn. which is all the more significant in that it lies within the sphere of influence of the Belgic culture, which Dr. R. E. Mortimer Wheeler has described in the St. Albans area. The exploration of the Roman villa which was discovered by accident at Welwyn some five years ago points to the probability that this was a Roman farm; but further investigation shows that it had been preceded by a British, or rather a Belgic, farm.

As was pointed out by $\mathrm{Mr}$. J. Ward Perkins, the excavator, in describing the site before the Society of Antiquaries on December 9, this is the first proved instance of the conversion of a preRoman into a Roman farm, although it would not be unreasonable to presume that this had happened with some frequency. The site is also notable for affording the rare evidence of a tower forming part of the Roman building. Such a tower might be presumed to be of frequent occurrence in Roman Britain, although actual traces of an upper story have not often been found. Here the lower part of the tower had walls of flint and brick, with coloured wall-plaster, while the upper part was of timber framing, probably filled with pisé-de-terre.

The result of the excavation at Welwyn is especially instructive from more than one point of view. The discovery of a pre-Roman agricultural occupation of the site links up with a number of discoveries of recent years bearing on the social and economic life of the period preceding the Roman invasion. That such discoveries have been made is to be traced in no small part to the efforts and influence of a research committee of the British Association, which directed attention to the significance of apparently unimportant and irrelevant finds on sites in Roman Britain by granting a small subsidy for many years to excavations on such sites in return for reports on the pre-Roman finds, which previously had been neglected. The growth from these small beginnings vindicates the prescience of those by whom the committee was instituted.

Further, and in the same connexion, the Welwyn excavation illustrates the advantages which may accrue from investigating the small and superficially unimportant site. 